\title{
FAKTOR MINAT BERDONASI PADA LEMBAGA AMIL ZAKAT SAHABAT MUSTAHIQ1
}

\author{
Ricky Nuari \\ Departemen Ekonomi Syariah - Fakultas Ekonomi dan Bisnis - Universitas Airlangga \\ Email: Rickynuari17@gmail.com \\ Achsania Hendratmi \\ Departemen Ekonomi Syariah - Fakultas Ekonomi dan Bisnis - Universitas Airlangga \\ Email: nia_rachmadi@yahoo.com
}

\begin{abstract}
:
The lack of information in understanding the factors of donors' interest in donating to charitable institutions is the reason for the lack of optimization of the collection of donations. This study aims to determine the effect of age, income, education, generosity, financial security and religiosity on the interest in donating to LAZ Sahabat Mustahiq. This study uses a quantitative approach with multiple linear regression analysis methods and data collection by distributing questionnaires to 107 permanent donors, Friends of Mustahiq. The results of this study showed that the independent variables partially showed that interest donors donated at LAZ Sahabat Mustahiq were influenced by religiosity. That is because the majority of the population of Muslim Indonesia adheres to their religion. Factors of age, income, education, financial security, and generosity partially have no effect on interest in donating. While simultaneously all independent variables influence interest in donating.
\end{abstract}

Keywords: Donation, Interest, Factors, Multiple Linear Regression.

\section{PENDAHULUAN}

Perilaku manusia dalam setiap aspek kehidupannya selalu berdasarkan Alquran dan Sunnah jadi dalam hal mengambil keputusan tidak bisa dilakukan semaunya saja (Hermansyah, 2015:115). Agama berpengaruh besar terhadap pertimbangan dan perilaku moral bagi masyarakat Indonesia. Islam mengatur segala aspek kehidupan seorang muslim bukan hanya untuk melakukan aturan/regulasi kognitif dan emosi tetapi juga regulasi perilaku atau lebih tepatnya regulasi perilaku islami. Islam bahkan secara detail mengatur perilaku manusia seperti halnya bangun tidur, berdoa sebelum melakukan suatu kebaikan, dan hal-hal kecil lainnya (Rahman, 2017:64-65).

Salah satu bentuk perilaku adalah pengambilan keputusan. Keputusan yang diambil seseorang dituntut untuk seimbang yaitu antara kebutuhan, preferensi dan ketersediaan sumberdaya. Keseimbangan sudah menjadi sunnatullah untuk seorang Muslim dalam segala hal. Dampak dari ketidakseimbangan yaitu akan menyebabkan runtuhnya nilai akhlak, budi pekerti manusia dan kehancurian dunia secara luas. Secara umum terdapat tiga keseimbangan yang diajarkan dalam Alquran kepada manusia, yaitu: 1. Keseimbangan hidup di dunia dan setelah kematian; 2. Keseimbangan kebutuhan jiwa dan raga;

\footnotetext{
${ }^{1}$ Jurnal ini merupakan bagian dari skripsi yang ditulis oleh Ricky Nuari, NIM: 041311433108, yang diuji pada 24 Juli 2019.
} 
3. Keseimbangan kepentingan individual dan masyarakat (Mochlasin, 2013:107108).

$\begin{array}{ccr}\text { Altruisme } & \text { dalam } & \text { Islam } \\ \text { diimplementasikan } & \text { dalam } & \text { bentuk }\end{array}$
diwajibkannya zakat pada tahun dua Hijriah, ada pula infak dan sedekah namun tidak sebatas itu, menjadi manusia yang bermanfaat bagi yang lain juga sebuah ajaran Islam. Semua komponen sifat altruis menjadi bagian dalam ajaran Islam salah satunya adalah berdonasi.

Meski intrumen berdonasi dalam perilaku altruistik seorang Muslim ada banyak (Zakat, Infak, Sedekah, Wakaf dsb) tapi yang diwajibkan hanya zakat dan itu orang-orang yang sudah dikategorikan Muzakki (orang wajib Zakat) masih terasa kurangnya minat berzakat dengan berbagai faktor penyebabnya. Hal tersebut dibuktikan dengan tercatat penerimaan dana Zakat pada Badan Amil Zakat Nasional (BAZNAS) 2015 sebesar Rp. 82.272.643.293 (Baznas.go.id) dengan jumlah penduduk Muslim Indonesia $224,634.000$ jiwa $187 \%$ dari Jumlah penduduk Indonesia tahun 2015) jika dihitung rata-rata perkapita berdonasi zakat sebesar Rp. 366,2.

Perilaku berdonasi memiliki faktor penentu yang mempengaruhi seseorang untuk memberikan donasi. Faktor umur yaitu bahwa usia yang lebih tua, tingkat pendapatan dan jenjang pendidikan yang tinggi, dan religiusitas berpengaruh pada donasi (Halim dkk., 2015:564). Faktor memiliki rasa kedermawanan dan pengalaman sukarelawan memiliki pengaruh pada seseorang untuk berdonasi (Schlegelmilch,

Diamantopoulos, dan Love, 1997: 16). Seseorang yang memiliki keamanan finansial (tidak khawatir dengan keadaan keuangan) berpengaruh untuk berdonasi (Michael Lwin dan Ian Phau, 2010).

Penelitian ini mengadopsi Schlegelmilch, Diamantopoulos, dan Love, (1997: 16) dalam membagi faktor yang mempengaruhi seseorang minat memberikan donasi yaitu karakteristik demografi terdiri dari faktor usia dan jenis kelamin,karakteristik sosial-ekonomi terdiri dari faktor tingkat pendapatan dan jenjang pendidikan, dan persepsi diri terdiri oleh faktor rasa kedermawanan, rasa keamanan finansial, religiusitas dan relawan.

Sahabat Mustahiq merupakan satu diantara banyak LAZ di Indonesia. LAZ Sahabat Mustahiq mengumpulkan donasi berupa zakat, infak dan sedekah dalam rangka pemberdayaan masyarakat dhua'fa dalam beberapa program kemanusiaan. Sahabat mustahia dalam menjalankan programnya untuk penghimpunan donasi saat ini lebih pada strategi jemput zakat dan pendekatan individu person to person atau door to door yaitu dengan melakukan pendekatan yang sama antar individu tanpa memperhatikan karakteristik siapa calon donaturnya seperti Gender, Jenjang pendidikan, pendapatan dan lain-lain. 
Penghimpunan donasi dengan person to person atau door to door di Sahabat Mustahiq dilakukan oleh Bagian marketing ZIS yang lebih fokus dalam mencari donatur baru, secara teknis bagian marketing ZIS keliling untuk menawarkan dan memfasilitasi seseorang yang menjadi calon donatur dengan membantu menghitungkan zakat dan memberikan edukasi tentang sadar akan pentingnya mengeluarkan ZIS.

Sahabat Mustahiq memiliki 28.670 donatur pada bulan Desember 2018dengan penerimaan donasi zakat sebesar Rp. 32.381.774 (Mustahiq.or.id). Sedangkan Jawa Timur (Jatim)donasi zakat yang terhimpun sebesar Rp. 32 miliar pada tahun 2015, pada tahun 2016 sebesar Rp. 42,7 miliar (Baznasjatim.or.id). Perbandingan antara Jumlah penghimpunan donasi zakat di Sahabat Mustahia dengan Badan Amil Zakat Nasional (BAZNAS) Jatim menunjukan angka pencapaian Sahabat Mustahia masih relatif kecil. Padahal penduduk Jawa Timur sebanyak 38.847.561 jiwa di tahun 2015 dan pada tahun 2016 sebanyak 39.075.152 jiwa dengan jumlah Muslim sebanyak $95 \%$ dari total penduduk (bappeda.jatimprov.go.id). maka masih besar kemungkinan untuk digali minat individu masyarakat Jatim dalam memberikan donasi pada LAZ Sahabat Mustahiq.

Gap atas perbedaan
penghimpunan zakat di Sahabat
Mustahiq dengan Jatim yang jumlah

penduduknya lebih kecil menandakan masalah kurang optimalnya penghimpunan zakat. Melihat pencapaian nilai donasi Sahabat Mustahiq yang masih rendah maka perlu dilakukan upaya penjaringan donatur baru. Mendapatkan donatur baru memang tidak mudah terbukti dari 6 orang Bagian Marketing ZIS Sahabat Mustahiq hanya 3-4 orang yang memenuhi nominal target yang sudah ditetapkan tiap bulan.

Terhadap target yang tidak terpenuhi maka identifikasi karakteristik individu terhadap minat memberikan donasi harus dilakukan penelitian lebih dalam. Jika hasil penelitian atas identifikasi karakteristik diketahui oleh LAZ Sahabat Mustahiq maka besar kemungkinan optimalisasi penghimpunan zakat akan terwujud karena telah memahami karakteristik individu yang mempengaruhi minat memberikan donasi. Berdasarkan uraian latar belakang atau permasalahan yang sudah dipaparkan maka penelitian skripsi di LAZ Sahabat Mustahiq dilakukan dengan judul: "Karakteristik yang mempengaruhi minat memberikan donasi pada Lembaga Amil Zakat Sahabat Mustahiq".

\section{LANDASAN TEORI}

Bodo B Schlegelmilch, dkk(1997) dengan judul Characteristics affecting charitable donations: empirical evidence from Britain. Penelitian ini menggunakan metode analisis diskriminan, Variabel dependen dalam analisis adalah 
kategorisasi ke dalam donatur dan nondonatur, berdasarkan pada apakah responden mengaku telah menyumbangkan uang untuk amal dalam bulan sebelum wawancara. Hasil penelitian menggambarkan bahwa Gender, umur dan keamanan finansial berpengaruh negatif pada perilaku berdonasi masyarakat Inggris, namun pendapatan, jenjang pendidikan, perasaan kedermawanan dan religiusitas menghasilkan pengaruh positif terhadap perilaku berdonasi.

Michael Lwin, dkk (2013) dengan judul Charitable donations: empirical evidence from brunei. Penelitian ini mereplikasi Schlegelmilch, dkk (1997). Data dianalisis menggunakan SPSS, dengan analisis faktor yang dilakukan sebelum menerapkan serangkaian t-tes dan ANOVA, skala yang digunakan adalah skala likert. Hasil penelitian menggambarkan bahwa jenis kelamin, umur, pendapatan, kemananan finasial dan perasaan kedermawanan, pikiran dunia berpengaruh negatif pada perilaku berdonasi masyarakat brunei, sedangkan tingkat pendidikan, religiusitas dan persepsi amal berpengaruh positif pada perilaku berdonasi.

Penelitian ini mengadaptasi dan memodifikasi kuesioner Schlegelmilch, dkk (1997).Penelitian menggunakan jenis data cross section memakai perangkat lunak. Hasil penelitian menggambarkan bahwa jenis kelamin, dan umur berpengaruh negatif pada perilaku berdonasi masyarakat Pakistan, sedangkan tingkat pendidikan, pendapatan, keamanan finansial, rasa kedermawanan, sikap individu, kampanye penggalangan dana, kepercayaan pada donatur dan religiusitas berpengaruh positif pada perilaku berdonasi.

Abd Halim Bin Mohd Noor et.al. (2015) dengan judul Characteristic Affecting Charitable donations behavior: empirical evidence from Malaysia. Penelitian ini menggunakan dan mengadopsi data dianalisis dengan menggunakan analisis faktor dan regresi logistik. Ukuran sampel penelitian adalah 556 responden. Hasil penelitian menggambarkan bahwa jenis kelamin, keamanan finansial, dan rasa kedermawanan berpengaruh negatif pada perilaku berdonasi masyarakat Malaysia, sedangkan tingkat pendidikan, umur, pendapatan, dan religiusitas berpengaruh positif pada perilaku berdonasi.

Gambar 2.1Model Analisis

\begin{tabular}{|l|}
\hline Karakteristik Demografi \\
1. Umur \\
\hline $\begin{array}{l}\text { Karakteristik Sosio-Ekonomi } \\
\text { 2. Tingkat Pendidikan }\end{array}$ \\
\hline Persepsi Diri \\
1. Rasa Kedermawanan \\
3. Religiusitas Keamanan Finansial \\
\hline
\end{tabular}


Sumber: (Halim dkk, 2015), (Schlegelmilchdkk, 1997), (Awan\& Hameed, 2014), (Lwin, Phau\& Lim, 2013) dan(Lwin\&Phau, 2010), diolah.

\section{METODE PENELITIAN}

Penelitian ini memakai pendekatan kuantitatif menggunakan data primer dengan cara menyebar kuesioner kepada 107 responden yang berasal dari donator tetap LAZ Sahabat Mustahiq yang berjumlah 28.670 donatur tahun 2018. Kuesioner mengadopsi dan memodifikasi dari Halim dkk (2015), Schlegelmilchdkk (1997), Awan \& Hameed (2014), Lwin, Phau \& Lim (2013) dan Lwin \& Phau (2010).

$\begin{array}{ccc}\text { Pengambilan Sampel } & 107 \\ \text { responden dalam penelitian ini }\end{array}$
menggunakan teknik probability sampling yaitu teknik pengambilan sampel yang member peluang atau kesempatan sama bagi setiap unsure atau anggota populasi untuk dipilih menjadi sampel. Teknik probability sampling yaitu memberikan kesempatan yang sama kepada setiap anggota populasi untuk menjadi sampel yang dilakukan meliputi seluruh donatur LAZ Sahabat Mustahiq dan pemilihan sampel dilakukan secara acak (random). Metode analisis yang digunakan dalam penelitian ini adalah analisis regresi berganda dengan memakai software SPSS versi 16.00 .

Hipotesis merupakan jawaban sementara terhadap rumusan masalah penelitian. Maka dapat diajukan hipotesis sebagai berikut:

$\mathrm{H} 1$ : Umur berpengaruh terhadap minat berdonasi di LAZ Sahabat Mustahiq

H2: Pendapatan berpengaruh terhadap minat berdonasi di LAZ Sahabat Mustahia

H3: Pendidikan berpengaruh terhadap minat berdonasi di LAZ Sahabat Mustahiq

H4: Religiusitas berpengaruh terhadap minat berdonasi di LAZ Sahabat Mustahia

H5: Keamanan finansial berpengaruh terhadap minat berdonasi di LAZ Sahabat Mustahia

H6: Kedermawanan berpengaruh terhadap minat berdonasi di LAZ Sahabat Mustahiq.

H7: Umur, pendapatan, pendidikan, religiusitas, keamanan financial dan kedermawanan secara simultan berpengaruh terhadap minat berdonasi di LAZ Sahabat Mustahiq.

\section{HASIL DAN PEMBAHASAN}

Pembahasan hasil olah data dengan SPSS Versi 16.00 untuk menjawab dan menginterpretasikan terkait hipotesis yang diajukan diawal. Pembahasan atas hasil juga menjelaskan teori dan penelitian sebelumnya yang mendukung dan menolak atas hasil hipotesis. Tiap hipotesis dibahas dalam penelitian ini yaitu sebagai berikut:

Koefisien Regresi dan Uji T 
Tabel 1.

Koefisien Regresi dan Uji T

\begin{tabular}{|c|c|c|c|c|c|c|c|}
\hline \multirow[b]{2}{*}{ Model } & \multicolumn{2}{|c|}{$\begin{array}{l}\text { Unstandardized } \\
\text { Coefficients }\end{array}$} & \multirow{2}{*}{$\begin{array}{c}\begin{array}{c}\text { Standardized } \\
\text { Coefficients }\end{array} \\
\text { Beta }\end{array}$} & \multirow[b]{2}{*}{ T } & \multirow[b]{2}{*}{ Sig. } & \multicolumn{2}{|c|}{$\begin{array}{l}\text { Collinearity } \\
\text { Statistics }\end{array}$} \\
\hline & B & Std. Error & & & & Tolerance & VIF \\
\hline 1 (Constant) & 13.849 & 3.849 & & 3.598 & .001 & & \\
\hline (X1) UMUR & -.228 & .351 & -.058 & -.650 & .517 & .982 & 1.018 \\
\hline (X2) PENDAPATAN & -.764 & .429 & -.163 & 1779 & .078 & .923 & 1.084 \\
\hline (X3) PENDIDIKAN & .540 & .372 & .134 & 1.453 & .149 & .918 & 1.089 \\
\hline (X4) RELIGIUSITAS & .371 & .134 & .271 & 2.761 & .007 & .810 & 1.234 \\
\hline $\begin{array}{l}\text { (X5) KEAMANAN } \\
\text { FINANSIAL }\end{array}$ & .084 & .046 & .179 & 1.830 & .070 & .817 & 1.224 \\
\hline $\begin{array}{l}(\mathrm{X} 6) \\
\text { KEDERMAWANAN }\end{array}$ & .221 & 140 & .160 & 1.572 & .119 & .749 & 1.335 \\
\hline
\end{tabular}

Sumber: Olah Data Peneliti, 2019.

Dari tabel 1 di atas dapat diketahui bahwa a atau konstanta sebesar 13.849 artinya ketiga variabel yaitu kepercayaan, religiusitas dan pendapatan mempunyai pengaruh yang positif terhadap variabel minat sebesar 13.849, koefisien regresi variabel umur atau $X 1$ sebesar -0.228 , pendapatan atau X2 sebesar -0.764 , pendidikan atau $X 3$ sebesar 0.540, religiusitas atau X4 sebesar 0.371 , keamanan finansial atau $X 5$ sebesar 0.084 dan kedermawanan atau X6 sebesar 0.221. Dengan demikian model persamaan regesi yang diperoleh adalah sebagai berikut:

$Y=13.849+-0.228 \times 1+-0.764 \times 2+0.540 \times 3+$ $0.371 \times 4+0.084 \times 5+0.221 \times 6+e$

Dimana:

$Y=$ variabel dependen (minat donasi)

$\mathrm{X} 1$ = variabel independen (umur), $\mathrm{X} 2=$ variabel independen (pendapatan) $\mathrm{X} 3$ = variabel independen (pendidikan), X4 = variabel independen (religiusitas)
$\mathrm{X} 5$ = variabel independen (keamanan finansial), $X 6=$ variabel independen (kedermawanan)

Uji F

Tabel 4.2 Hasil Uji F

\begin{tabular}{|l|r|r|r|r|r|}
\hline Model & $\begin{array}{r}\text { Sum of } \\
\text { Squares }\end{array}$ & df & $\begin{array}{c}\text { Mean } \\
\text { Squar } \\
\mathrm{e}\end{array}$ & $\mathrm{F}$ & Sig. \\
\hline $\begin{array}{l}\text { 1 Regressio } \\
\mathrm{n}\end{array}$ & 263.703 & 6 & 43.950 & $\begin{array}{r}4.74 \\
.000 \\
9\end{array}$ \\
Residual & 925.437 & 10 & 9.254 & & \\
Total & 1189.14 & 10 & & & \\
& 0 & & & \\
\hline
\end{tabular}

Sumber: Olah Data Peneliti, 2019.

Dari tabel 4.2 di atas dapat diketahui bahwa dari uji ANOVA atau uji $F$ didapat nilai $F$ hitung sebesar 4.749 dan signifikan pada $0,000<$ dari $a=0.05$ maka dengan demikian dapat disimpulkan bahwa variabel independen umur, pendapatan, pendidikan, religiusitas, keamanan finansial dan kedermawanan 
secara bersama-sama atau simultan mempengaruhi variabel dependen yaitu minat berdonasi pada Lembaga Amil Zakat Sahabat Mustahiq.

Pengaruh umur terhadap minat berdonasi pada Lembaga Amil Zakat Sahabat Mustahiq.

Umur menjadi faktor penentu penting dalam evaluasi dampak pada minat berdonasi karena merupakan salah satu bagian dari demografi populasi. Hasil penelitian bisa menjadi bahan pengembangan rencana dan stategi pemasaran dalam meningkatkan donasi (Awan \& Hameed, 2014).

Hasil uji empiris pengaruh umur terhadap minat donasi pada Lembaga Amil Zakat Sahabat Mustahiq menunjukkan nilai $\dagger$ hitung -0.650 dan $p$ value (sig) sebesar 0.517 diatas alpha $5 \%$. Artinya bahwa umur tidak berpengaruh terhadap minat donasi pada Lembaga Amil Zakat Sahabat Mustahiq. Nilai beta dalam Unstandardized Coefficients variabel umur menunjukkan angka sebesar -0.228, artinya bahwa besaran koefisien umur terhadap minat donasi pada Lembaga Amil Zakat Sahabat Mustahiq $-22.8 \%$.

Hasil penelitian ini sejalan dengan penelitian sebelumnya yaitu Umur tidak berpengaruh terhadap perilaku berdonasi (Schlegelmilch dkk, 1997; Lwin, Phau \& Lim, 2013; Awan \& Hameed, 2014). Setiap orang memberikan donasi untuk meningkatkan kepuasan dalam batin, maka setiap orang dalam kelompok umur berapapun dapat memberikan donasinya demi kepuasan batin sehingga itulah sebabnya tidak ada pengaruh faktor umur terhadap pemberian donasi (Awan \& Hameed, 2014).

Pengaruh pendapatan terhadap minat berdonasi pada Lembaga Amil Zakat Sahabat Mustahiq.

Pendapatan merupakan faktor penentu penting dalam minat berdonasi, karena donasi yang dikeluarkan lebih banyak berupa uang bukan berupa benda. Tetapi dalam penelitian ini pendapatan seseorang yang besar tidak mempengaruhi seseorang untuk berdonasi, berarti pendapatan besar ataupun kecil sama saja. Hal ini berdasarkan fakta yang dikemukakan oleh Bennett (dalam Lwin \& Phau, 2010) bahwa orang dengan pendapatan sedikit atau rendah cenderung berdonasi kepada orang yang membutuhkan, karena mereka lebih memiliki rasa empati terhadap orang yang membutuhkan. Pada penelitian sebelumnya yaitu di Negara Brunei Darussalam mendapatkan hasil bahwa pendapatan tidak berpengaruh pada perilaku berdonasi (Lwin, Phau \& Lim, 2013). Pendapatan yang tinggi dari setiap orang Brunei tidak mempengaruhi perilaku berdonasi, karena faktanya bahwa Brunei adalah Negara kaya minyak (Halim dkk., 2015).

Hasil uji empiris pengaruh pendapatan terhadap minat donasi pada Lembaga Amil Zakat Sahabat Mustahiq menunjukkan nilai † hitung - 1.779 
dan $\mathrm{p}$ value (sig) sebesar 0.078 diatas alpha 5\%. Artinya bahwa pendapatan tidak berpengaruh terhadap minat donasi pada Lembaga Amil Zakat Sahabat Mustahiq. Nilai beta dalam unstandardized coefficients variabel pendapatan menunjukkan angka sebesar -0.764, artinya bahwa besaran koefisien pendapatan terhadap minat donasi pada Lembaga Amil Zakat Sahabat Mustahiq $-76.4 \%$.

\section{Pengaruh pendidikan terhadap minat berdonasi pada Lembaga Amil Zakat Sahabat Mustahiq.}

Hasil uji empiris pengaruh pendidikan terhadap minat donasi pada Lembaga Amil Zakat Sahabat Mustahiq menunjukkan nilai $t$ hitung 1.453 dan $\mathrm{p}$ value (sig) sebesar 0.149 diatas alpha $5 \%$. Artinya bahwa pendidikan tidak berpengaruh terhadap minat donasi pada Lembaga Amil Zakat Sahabat Mustahiq. Nilai beta dalam unstandardized coefficients variabel pendidikan menunjukkan angka sebesar 0.540, artinya bahwa besaran koefisien pendidikan terhadap minat donasi pada Lembaga Amil Zakat Sahabat Mustahia $54 \%$.

Hasil penelitian ini sejalan dengan penelitian sebelumnya yang dilakukan oleh Schlegelmilch dkk (1997) bahwa ada bukti untuk mendukung bahwa tingkat pendidikan tidak mempengaruhi untuk berdonasi dan pada literatur lebih lanjut menegaskan bahwa seorang yang tidak lulus sekolah atau putus sekolah pada usia dini cenderung untuk memberikan donasi kepada badan amal dibandingkan dengan orang yang pendidikan lebih tinggi. Pendidikan lebih tinggi juga tidak berpengaruh pada perilaku berdonasi masyarakat Australia disebabkan oleh hukum imigrasi Australia. Imigran Australia persentase besarnya adalah sabagai pengungsi dan mereka kemungkinan tidak memiliki tingkat pendidikan yang tinggi (Lwin \& Phau, 2010).

\section{Pengaruh religiusitas terhadap minat berdonasi pada Lembaga Amil Zakat Sahabat Mustahiq.}

Hasil uji empiris pengaruh religiusitas terhadap minat donasi pada Lembaga Amil Zakat Sahabat Mustahiq menunjukkan nilai $t$ hitung 2.761 dan $p$ value (sig) sebesar 0.007 dibawah alpha 5\%. Artinya bahwa religiusitas berpengaruh terhadap minat donasi pada Lembaga Amil Zakat Sahabat Mustahiq. Nilai beta dalam Unstandardized Coefficients variabel religiusitas menunjukkan angka sebesar 0.371, artinya bahwa besaran koefisien religiusitas terhadap minat donasi pada Lembaga Amil Zakat Sahabat Mustahia $37.1 \%$.

Hasil penelitian tersebut diperkuat dengan penelitian sebelumnya, menurut Kasri (dalam Halim dkk, 2015) bahwa religiusitas sangat memainkan peran penting dalam motivasi terbesar seseorang untuk berdonasi, terutama seorang Muslim yang cenderung memberikan donasi karena tanggung 
jawab terhadap masyarakat. Religiusitas mempengaruhi perilaku berdonasi di Malaysia (Halim dkk, 2015), Inggris (Schlegelmilch dkk, 1997), Pakistan (Awan \& Hameed, 2014), dan Brunei (Lwin, Phau \& Lim, 2013). Beda halnya dengan penelitian di Australia (Lwin \& Phau, 2010) yang berdampak sebaliknya yaitu Religiusitas tidak berpengaruh terhadap perilaku berdonasi dikarenakan persentase besar penduduk Australia tidak beragama atau atheis.

\section{Pengaruh keamanan finansial terhadap} minat berdonasi pada Lembaga Amil Zakat Sahabat Mustahiq.

Hasil uji empiris pengaruh keamanan finansial terhadap minat donasi pada Lembaga Amil Zakat Sahabat Mustahiq menunjukkan nilai $\dagger$ hitung 1.830 dan $\mathrm{p}$ value (sig) sebesar 0.070 diatas alpha 5\%. Artinya bahwa keamanan finansial tidak berpengaruh terhadap minat donasi pada Lembaga Amil Zakat Sahabat Mustahiq. Nilai beta dalam unstandardized coefficients variabel keamanan finansial menunjukkan angka sebesar 0.084, artinya bahwa besaran koefisien keamanan finansial terhadap minat donasi pada Lembaga Amil Zakat Sahabat Mustahia 8.4\%.

Hasil penelitian ini diperkuat dengan hasil yang ditemukan di Inggris, Malaysia dan Brunei oleh Halim dkk. (2015), Schlegelmilch dkk. (1997), Lwin, Phau \& Lim (2013)yang mengemukakan bahwa donatur yang memiliki keamanan finansial tidak berpengaruh terhadap donasinya ke lembaga amal. Artinya bahwa donator merupakan seseorang yang sudah aman secara finansial atau tidak terlalu khawatir tentang kondisi keuangan mereka di masa depan. Keamanan finansial yang dirasakan setiap orang menjadi faktor penentu untuk menentukan apakah responden merupakan donator potensial. Keamanan finansial sebagai indikator bagus untuk variabel intrinsik yang mempengaruhi perilaku berdonasi (Kasri, 2013).

Pengaruh kedermawanan terhadap minat donasi pada Lembaga Amil Zakat Sahabat Mustahiq.

Hasil uji empiris pengaruh kedermawanan terhadap minat donasi pada Lembaga Amil Zakat Sahabat Mustahiq menunjukkan nilai † hitung 1.572 dan $\mathrm{p}$ value (sig) sebesar 0.119 diatas alpha 5\%. Artinya bahwa kedermawanan tidak berpengaruh terhadap minat donasi pada Lembaga Amil Zakat Sahabat Mustahiq. Nilai beta dalam unstandardized coefficients variabel kedermawanan menunjukkan angka sebesar 0.221, artinya bahwa besaran koefisien kedermawanan terhadap minat donasi pada Lembaga Amil Zakat Sahabat Mustahiq 22.1\%.

Hasil penelitian ini sejalan dengan penelitian sebelumnya yang dilakukan oleh Halim dkk. (2015) yaitu bahwa rasa kedermawanan tidak berpengaruh terhadap Minat memberikan donasi masyarakat di Malaysia. Penelitian di Brunei oleh Lwin, Phau \& Lim (2013) 
menunjukkan hal yang sama bahwa kedermawanan yang dirasakan tidak memainkan peran penting di masyarakat Brunei, penyebabnya adalah pengaruh budaya di Brunei. Artinya tanggung jawab besar dalam pengumpulan donasi dan kegiatan amal lainnya dijalankan sepenuhnya oleh pemerintah. Oleh sebab itu, mungkin berdampak pada kedermawanan yang dirasakan dan "tidak tahu" akan kemurahan hati yang dirasakan pada dirinya sendiri karena kurangnya pengalaman berdonasi atau bisa karena berdonasi adalah hal biasa yang sudah bagian dari kehidupan seharihari pemerintah Brunei dan masyarakatnya sehingga mempertanyakan terkait pertanyaan indikator rasa kedermawanan responden bukanlah faktor penting bagi orangorang.

\section{SIMPULAN}

Kesimpulan dari hasil dan pembahasan yang menjawab rumusan masalah dari karakteristik yang mempengaruhi minat memberikan donasi pada Lembaga Amil Zakat Sahabat Mustahiq :

1. Umur berpengaruh tidak signifikan terhadap minat memberikan donasi pada Lembaga Amil Zakat Sahabat Mustahiq

2. Pendapatan berpengaruh tidak signifikan terhadap minat memberikan donasi pada Lembaga Amil Zakat Sahabat Mustahiq
3. Pendidikan berpengaruh tidak signifikan terhadap minat memberikan donasi pada Lembaga Amil Zakat Sahabat Mustahiq.

4. Religiusitas berpengaruh signifikan terhadap minat memberikan donasi pada Lembaga Amil Zakat Sahabat Mustahiq

5. Keamanan financial berpengaruh tidak signifikan terhadap minat memberikan donasi pada Lembaga Amil Zakat Sahabat Mustahia

6. Kedermawanan berpengaruh tidak signifikan terhadap minat memberikan donasi pada Lembaga Amil Zakat Sahabat Mustahiq.

7. Religiusitas berpengaruh signifikan terhadap minat memberikan donasi pada Lembaga Amil Zakat Sahabat Mustahiq.

\section{DAFTAR PUSTAKA}

Halim, A., Isa, N., Irpan, H., Hasan, Arifin, Abdul Rahim. (2015). Characteristic Affecting Charitable Donations Behaviour: Empirical Evidence from Malaysia. Procedia Economics and Finance $31,563-572$.

Schlegelmilch, Diamantopoulos, Love. (1997). Characteristics affecting charitable donations: empirical evidence from Britain. Journal of Marketing Science, 14-28.

Lwin, Phau, Lim. (2013). Charitable donations: empirical evidence from brunei. Asia-Pacific Journal of Business Administration 5 (3), 215233. 
Awan, Hameed. (2014). The effect of demographic, socio-economic and other characteristics on donations. Current Research Journal of Social Sciences 6 (2), 5576

Lwin, Phau. (2010). Characteristics of Charitable Donors in Australia. Curtin institutional Research Repository.

Kasri, RahmatinaAwaliah. (2013). Giving Behaviors in Indonesia: Motives and Marketing Implications for Islamic Charities. Journal of Islamic Marketing, 4 (3).

Qardawi, Yusuf. (2004). Hukum Zakat: StudiKomperatifMengenai Status danFilsafat Zakat Berdasarkan Qur'an danHadits. Jakarta: PT. MitraKerjaya Indonesia.

BAZNAS. (2013). Potensi Zakat Nasional. Majalah Zakat, Mei-Juni, hlm. 7.
Yunus, M. (2016). Analisis Pengaruh Kepercayaan, Religiusitas, dan Kontribusi Terhadap Minat Pedagang Mengeluarkan Zakat di Baitul Mal (Studi Kasus Pada Pedagang Pasar Los Lhokseumawe). At-Tawassuth, I (1), 95-124.

BPPK Kemenkeu. https://bppk.kemenkeu.go.id/id/ publikasi/artikel/167-artikelpajak/21014-penghasilan-kelasmenengah-naik-potensi-pajak. Diaksespadatanggal 11 April 2019.

Rahman, Agus Abdul. (2017). RegulasiPerilakulslami, Kesadaran Moral, danKemunafikan. JurnalPsikologi, 13 (1).

Admin

Mustahiq.or.id.

Diaksespadatanggal 11 April 2019. 